\title{
Food protein-induced enterocolitis syndrome and allergic proctocolitis
}

\author{
Anna Nowak-Węgrzyn, M.D.
}

\begin{abstract}
Non-IgE-mediated food allergic disorders account for up to $40 \%$ of milk protein allergy in infants and young children. We aim to review the recent literature and to provide an update on diagnosis and management of food protein-induced enterocolitis syndrome (FPIES) and food protein-induced allergic proctocolitis (FPIAP). The peer-reviewed articles indexed in PubMed have been reviewed. FPIES manifests in infants as profuse, repetitive vomiting and lethargy, often with diarrhea, leading to acute dehydration, or weight loss and failure to thrive, in chronic form. FPIES is caused most commonly by cow's milk (CM) and soy proteins; rice, oat, and other solid foods may also trigger FPIES. FPIES rarely occurs in the exclusively breastfed infants. FPIES is underrecognized; children are often mismanaged as having acute viral gastrointestinal illness, sepsis, or surgical disease, delaying diagnosis of FPIES for many months. Approximately 25\% of children with FPIES develop food-specific IgE antibodies and some transition to immediate food allergy; IgE positivity is associated with a more protracted course. FPIES is a self-limiting condition, with most cases resolving by age three to five years. Ondansetron may be helpful in managing acute FPIES. FPIAP is a benign condition of bloody stools in a well-appearing infant, with usual onset between one and four weeks of age. Up to $60 \%$ of cases occur in exclusively breastfed infants and resolve with maternal elimination of CM and soy proteins. The majority of cases resolve by age 12 months. FPIES may transition to IgE-mediated food allergy in some patients; IgE positivity to the FPIES food is a marker of a more persistent disease. FPIAP is benign and resolves by age 12 months in most patients.
\end{abstract}

(Allergy Asthma Proc 36:172-184, 2015; doi: 10.2500/aap.2015.36.3811)

$\mathbf{N}^{\circ}$ n-IgE, cell-mediated food allergic disorders encompass food protein-induced enterocolitis syndrome (FPIES), food protein-induced allergic proctocolitis (FPIAP), food protein-induced enteropathy, Heiner's syndrome (pulmonary hemosiderosis), celiac disease, and cow's milk $(\mathrm{CM})$ protein-induced iron deficiency anemia. ${ }^{1,2}$ Because celiac disease is traditionally managed by gastroenterologists, and food protein-induced enteropathy, Heiner's syndrome, and CM protein-induced iron deficiency have become exceedingly rare in the past four decades, this review focuses on FPIES and FPIAP. Cell-mediated allergic reactions to CM proteins are common and are estimated to account for approximately $40 \%$ of CM allergy in infants and young children. The overview of the major cell-mediated food allergic disorders, excluding celiac disease, is presented in Table 1.

\section{FPIES}

FPIES manifests usually in infants as profuse repetitive emesis (onset one to three hours after ingestion) and diarrhea (onset 5-10 hours) that may be accompanied by lethargy. ${ }^{3}$ The respiratory and skin manifestations are absent in FPIES reactions. ${ }^{4}$ FPIES is most commonly caused by CM and soy. ${ }^{5-9}$ Symptoms may start in the newborn period or up to one year of age. ${ }^{10,11}$ Later onset usually results from delayed introduction of CM, soy, or solid foods to breastfed infants. ${ }^{9}$ In most reports, CM and/or soy FPIES in exclusively breastfed infants is very rare, suggesting an important protective role of breastfeeding. ${ }^{12,13}$ However, in a cohort of Japanese 30 infants with CM FPIES, 10\% developed symptoms during breastfeeding, suggesting that FPIES phenotype may be expressed differentially in various ethnic groups. ${ }^{14,15}$ FPIES to solid foods such as grains (rice, oat), meats, fish, egg, and vegetables have been reported. ${ }^{3}$ FPIES to fish or shellfish usually starts in older children and adults..$^{9,16}$

\section{Clinical Features of FPIES}

The manifestations of FPIES are modified by frequency and dose of ingested food antigen.

\section{Infantile Chronic FPIES}

In the most severe cases, symptoms start within first days of life in infants fed with CM- or soy-based for- 
Table 1. Comparison of FPIES, FPIAP, food protein-induced enteropathy, and iron deficiency anemia due to $\mathrm{CM}$

\begin{tabular}{|c|c|c|c|c|}
\hline & FPIES & FPIAP & Enteropathy & $\begin{array}{c}\text { Iron Deficiency } \\
\text { Anemia }\end{array}$ \\
\hline Age at onset & One day-one year & $\begin{array}{l}\text { Days to six } \\
\text { months, } \\
\text { usually one } \\
\text { to four weeks }\end{array}$ & $\begin{array}{l}\text { Dependent on age } \\
\text { of exposure to } \\
\text { antigen; CM } \\
\text { and soy up to } \\
\text { two years }\end{array}$ & 2-20 months \\
\hline \multicolumn{5}{|l|}{$\begin{array}{l}\text { Food proteins } \\
\text { implicated }\end{array}$} \\
\hline Most common & CM, soy & CM, soy & $\mathrm{CM}$, soy & $\mathrm{CM}$ \\
\hline Less common & $\begin{array}{l}\text { Rice, oat, barley, } \\
\text { chicken, turkey, } \\
\text { fish, pea }\end{array}$ & & Wheat, egg & \\
\hline $\begin{array}{l}\text { Multiple food } \\
\text { hypersensitivities }\end{array}$ & $\begin{array}{l}\text { About } 40 \% \text { both } \\
\text { CM and soy }\end{array}$ & $\begin{array}{l}\text { Up to } 20 \% \text { may } \\
\text { react to } \mathrm{CM} \\
\text { and soy or } \\
\text { multiple } \\
\text { foods }\end{array}$ & Rare & No \\
\hline $\begin{array}{l}\text { Feeding at the time } \\
\text { of onset }\end{array}$ & Formula & Breast milk & Formula & $\begin{array}{l}\text { CM, nonhumanized } \\
\text { CM-based } \\
\text { formula }\end{array}$ \\
\hline \multicolumn{5}{|l|}{ Atopic background } \\
\hline $\begin{array}{l}\text { Family history of } \\
\text { atopy }\end{array}$ & $40 \%-70 \%$ & $25 \%$ & Unknown & Unknown \\
\hline $\begin{array}{l}\text { Personal history } \\
\text { of atopy }\end{array}$ & $30 \%$ & $20 \%$ & $22 \%$ & Unknown \\
\hline \multicolumn{5}{|l|}{ Symptoms } \\
\hline Emesis & Prominent & Absent & Intermittent & No \\
\hline Diarrhea & Severe & Mild & Moderate & Minimal \\
\hline Bloody stools & Severe & Prominent & Rare & No \\
\hline Edema & Acute, severe & $\begin{array}{l}\text { Mild, } \\
\text { infrequent }\end{array}$ & Moderate & Mild \\
\hline Shock & $15 \%$ & No & No & No \\
\hline Failure to thrive & Moderate & No & Moderate & Minimal \\
\hline \multicolumn{5}{|l|}{ Laboratory findings } \\
\hline Anemia & Moderate & $\begin{array}{l}\text { Mild, } \\
\text { infrequent }\end{array}$ & Moderate & Moderate \\
\hline Hypoalbuminemia & Acute & $\begin{array}{l}\text { Mild, } \\
\text { infrequent }\end{array}$ & Moderate & Mild \\
\hline Methemoglobinemia & May be present & No & No & No \\
\hline Acidemia & May be present & No & No & No \\
\hline \multicolumn{5}{|l|}{ Allergy evaluation } \\
\hline $\begin{array}{l}\text { Food prick skin } \\
\text { test }\end{array}$ & Negative\# & Negative & Negative & Negative \\
\hline $\begin{array}{l}\text { Serum food- } \\
\text { allergen IgE }\end{array}$ & Negative\# & Negative & Negative & Negative \\
\hline Total IgE & $\begin{array}{c}\text { Normal or } \\
\text { elevated }\end{array}$ & $\begin{array}{c}\text { Normal or } \\
\text { elevated }\end{array}$ & Normal & Normal \\
\hline $\begin{array}{l}\text { Peripheral blood } \\
\text { eosinophilia }\end{array}$ & No & Occasional & No & No \\
\hline
\end{tabular}


FPIES

FPIAP

Enteropathy

Iron Deficiency Anemia

\begin{tabular}{|c|c|c|c|c|}
\hline \multicolumn{5}{|l|}{ Biopsy findings } \\
\hline Villous injury & Patchy, variable & No & $\begin{array}{l}\text { Variable, } \\
\text { increased crypt } \\
\text { length }\end{array}$ & Mild \\
\hline Colitis & Prominent & Focal & No & No \\
\hline Mucosal erosions & Occasional & $\begin{array}{l}\text { Occasional, } \\
\text { linear }\end{array}$ & No & No \\
\hline $\begin{array}{l}\text { Lymphoid } \\
\text { nodular } \\
\text { hyperplasia }\end{array}$ & No & Common & No & No \\
\hline Eosinophils & Prominent & Prominent & Few & No \\
\hline Food challenge & $\begin{array}{l}\text { Vomiting in 3-4 } \\
\text { hours; diarrhea } \\
\text { in five to eight } \\
\text { hours }\end{array}$ & $\begin{array}{l}\text { Usually not } \\
\text { necessary }\end{array}$ & $\begin{array}{l}\text { Vomiting and/or } \\
\text { diarrhea in } 40- \\
72 \text { hours }\end{array}$ & $\begin{array}{l}\text { Usually not } \\
\text { necessary }\end{array}$ \\
\hline Treatment & $\begin{array}{l}\text { Protein } \\
\text { elimination, } \\
80 \% \text { respond to } \\
\text { casein } \\
\text { hydrolysate and } \\
\text { symptoms clear } \\
\text { in 3-10 days; } \\
\text { rechallenge in } \\
1.5-2 \text { years }\end{array}$ & $\begin{array}{l}\text { Protein } \\
\text { elimination } \\
\text { from the } \\
\text { maternal diet } \\
\text { or } \\
\text { hypoallergenic } \\
\text { formula, } \\
\text { approximately } \\
10 \% \text { may } \\
\text { need } \\
\text { elemental } \\
\text { formula } \\
\text { Reintroduce } \\
\text { food protein } \\
\text { after } 12 \\
\text { months }\end{array}$ & $\begin{array}{l}\text { Protein } \\
\text { elimination, } \\
\text { symptoms clear } \\
\text { in one to three } \\
\text { weeks, } \\
\text { rechallenge and } \\
\text { biopsy in one to } \\
\text { two years }\end{array}$ & $\begin{array}{l}\text { Whole CM protein } \\
\text { elimination, } \\
\text { feeding with } \\
\text { humanized CM- } \\
\text { based formulas }\end{array}$ \\
\hline Natural history & $\begin{array}{l}\mathrm{CM}: 60 \% \\
\text { resolved by two } \\
\text { years } \\
\text { Soy: } 25 \% \\
\text { resolved by two } \\
\text { years }\end{array}$ & $\begin{array}{l}\text { Majority } \\
\text { resolve by } \\
\text { age } 12 \\
\text { months }\end{array}$ & $\begin{array}{l}\text { Most cases } \\
\text { resolve in two } \\
\text { to three years }\end{array}$ & $\begin{array}{c}\text { Most cases resolve } \\
\text { by three years }\end{array}$ \\
\hline $\begin{array}{l}\text { Reintroduction of } \\
\text { the food into the } \\
\text { diet }\end{array}$ & $\begin{array}{l}\text { Inpatient food } \\
\text { challenge }\end{array}$ & $\begin{array}{l}\text { Home, } \\
\text { gradually } \\
\text { advancing }\end{array}$ & $\begin{array}{l}\text { Home, gradually } \\
\text { advancing }\end{array}$ & $\begin{array}{l}\text { Home, gradually } \\
\text { advancing }\end{array}$ \\
\hline
\end{tabular}

FPIES $=$ food protein-induced enterocolitis syndrome; FPIAP $=$ food protein-induced allergic proctocolitis; $C M=$ cow's milk. \# = if positive, may be a risk factor for persistent disease.

mula with intermittent emesis and chronic diarrhea (may be bloody), without specific temporal association with food ingestion. ${ }^{14,17,18}$ Lethargy, abdominal distension, weight loss, dehydration, metabolic acidosis, anemia, elevated white blood count with eosinophilia, and hypoalbuminemia may follow. Intramural gas is seen on abdominal radiographs, prompting a diagnosis of necrotizing enterocolitis, sepsis evaluation, and antibiotic treatment. ${ }^{7,19}$ Overall, $75 \%$ of infants appear acutely ill; approximately $15 \%$ are hypotensive and require hospitalization. ${ }^{5}$ Transient methemoglobinemia was reported in $1 / 3$ of young infants with severe reactions and acidemia; some required treatment with methylene blue and bicarbonate. ${ }^{20}$ Methemoglobin- 
emia may be caused by an elevation of nitrites resulting from severe intestinal inflammation and reduced catalase activity.

\section{Acute FPIES}

Acute FPIES can be caused by CM, soy, and solid foods in infants and young children; in adults by seafood, especially mollusks. Symptomatic infants with chronic FPIES improve within 3-10 days with i.v. fluids or with hypoallergenic formula. ${ }^{18}$ Food reintroduction after a period of avoidance induces acute symptoms; usually, repetitive (up to 10-20 times), projectile, emesis starts within one to three hours after ingestion. Infants and children appear ill, pale, and lethargic. Diarrhea usually starts within 2-10 hours (mean onset, five hours) with blood, mucous, leukocytes, eosinophils, and increased carbohydrate content. ${ }^{18}$ Diarrhea is more common in infants and in severe reactions; diarrhea may be absent in less severe acute reactions (such as during the food challenge) and in older children. ${ }^{9}$ Some patients become hypotensive and develop hypovolemic shock. ${ }^{16,21,16}$ Peripheral blood neutrophil counts are elevated in positive challenges, peaking at six hours, and returning to baseline within 18-24 hours. ${ }^{18}$ In the extreme cases, severe abdominal distension may raise suspicion of ileus and leads to an exploratory laparotomy. ${ }^{22}$ The typical features of chronic and acute CM and soy FPIES are presented in Table 2.

\section{Offending Foods}

The majority $(\sim 60 \%)$ of patients react to a single food. ${ }^{6,9}$ The most common foods are CM and soy; up to $40 \%$ infants may react to both foods. FPIES may also be caused by other solid foods such as rice, oat, barley, chicken, turkey, egg white, green pea, and peanut. ${ }^{23-31}$ Mean age at onset of solid food FPIES tends to be higher than the mean age of onset of $\mathrm{CM}$ and soy FPIES, likely reflecting the older age of usual introduction of solids into the diet. ${ }^{9}$ Among infants with solid food FPIES, 65\% were previously diagnosed with CM and/or soy FPIES and fed with casein hydrolysate- or amino acid-based formula; 35\% were breastfed. ${ }^{19}$

\section{FPIES in Adults}

In adults, mollusks (scallop), crustacean shellfish, and fish hypersensitivity may provoke a similar syndrome with severe nausea, abdominal cramps, protracted vomiting, and diarrhea. ${ }^{16}$

\section{Epidemiology of FPIES}

Prevalence of FPIES in the United States is not known; in general, gastrointestinal immune reactions to $\mathrm{CM}$ proteins that are mediated by T-lymphocytes with or without contribution of specific $\operatorname{IgE}$ antibody are estimated to account for up to $40 \%$ of CM protein hypersensitivity in infants and young children. ${ }^{32}$ In a large unselected population-based birth cohort study in Israel, CM FPIES was reported in $0.34 \%$, whereas IgE-mediated food allergy was reported in $0.5 \%$ of the infants under 12 months of age. ${ }^{8}$

Family history of atopy is positive in $40 \%-80 \%$ of patients; family history is positive for food allergy in approximately $20 \%$ of the cases. ${ }^{19}$ Approximately $30 \%$ of infants with FPIES develop atopic diseases such as eczema $(23 \%-57 \%)$, asthma or rhinitis $(20 \%)$, or drug hypersensitivity later in life, similar to the general population. Up to $40 \%$ may have evidence of IgE positivity to other foods. ${ }^{6,9}$ Family history of FPIES is reported in $6 \%{ }^{9}$

\section{Diagnosis of FPIES}

Diagnosis is based on the history, clinical features, exclusion of other etiologies (Table 3), and food challenge (Table 4). ${ }^{4}$ Delayed diagnosis is common and may be due to the low index of suspicion due to the lack of typical cutaneous and respiratory allergic symptoms. Furthermore, rice, oat, and vegetables rarely cause IgE-mediated allergy, are considered hypoallergenic, and not suspected as culprits in severe allergic reactions. Lack of definitive diagnostic tests also contributes to the delayed diagnosis. In contrast to the majority of patients from United States, Europe, Australia, and Israel, $47 \%$ of Japanese infants with CM FPIES have detectable serum CM-specific IgE. ${ }^{14}$ Data from Japan suggest that race or ethnicity may influence FPIES phenotype. ${ }^{15}$

Based on the presumed pathophysiology involving $\mathrm{T}$ cells, atopy patch test (APT) was evaluated for diagnosis of FPIES, with conflicting results. Currently, APT is not recommended for FPIES diagnosis. 6,33,34

Oral food challenge (OFC) is the gold standard for diagnosing FPIES. However, most infants do not need to undergo confirmatory OFC for the initial diagnosis, especially if they have a classic history of severe, repeated reactions and become asymptomatic after elimination of the suspected food. ${ }^{1}$ OFCs are necessary to determine whether FPIES resolved and whether the food may be reintroduced into the diet.

Hypoalbuminemia and weight gain less than 10 $\mathrm{g} /$ day were identified as independent predictors of CM FPIES in young infants with chronic gastrointestinal symptoms. ${ }^{11}$ Stool examination in infants with chronic FPIES and diarrhea is nonspecific and shows occult blood, intact polymorphonuclear neutrophils, eosinophils, Charcot-Leyden crystals, and reducing substances.

Before establishment of the diagnostic criteria, endoscopy in symptomatic infants with CM and/or soy FPIES showed rectal ulceration and bleeding with friable mucosa. ${ }^{17}$ In infants with chronic diarrhea, rectal 


\section{Chronic* FPIES}

Food ingestion

Onset of symptoms

Symptoms and signs

Laboratory findings

Lethargy
Food ingested on a regular basis, initially described in young infants being fed with milk or soy-based formulas; food ingestion after a period of avoidance results in the symptoms of acute FPIES

Intermittent vomiting without clear temporal association with food ingestion, chronic diarrhea that may contain blood or mucous; may lead to weight loss or failure to thrive

Intermittent vomiting

Diarrhea

Pallor

Weight loss

Failure to thrive

Severe

Bilious vomiting

Bloody diarrhea

Abdominal distention

Dehydration

Limpness

Dusky appearance

Anemia

Hypoalbuminemia

Leukocytosis with left shift

Eosinophilia

Metabolic acidosis

Methemoglobulinemia

Stool reducing substances
Acute FPIES

Food ingested on an intermittent basis or after a longer period of avoidance

Typical onset of vomiting in one to three hours, accompanied by pallor, lethargy; may be followed by diarrhea in five to eight hours in some patients

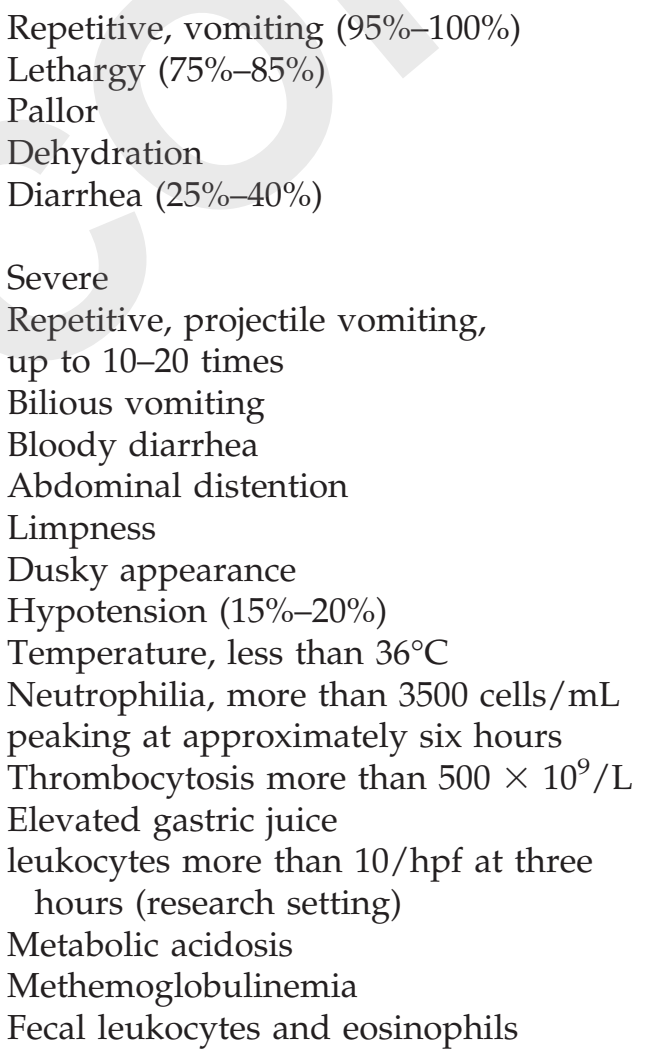

FPIES = food protein-induced enterocolitis syndrome; FPIAP = food protein-induced allergic proctocolitis; ${ }^{*}=$ chronic FPIES phenotype has been reported in young infants continuously fed with milk or soy-based formula. It is unclear whether chronic FPIEs can be caused by solid foods in older children.

Source: Ref. 56. Reprinted with permission from Nowak-Wegrzyn and Konstantinou.

bleeding, and/or failure to thrive, radiographs showed air fluid levels, nonspecific narrowing and thumbprinting of the rectum and sigmoid, and thickening of the plicae circulares in the duodenum and jejunum with excess luminal fluid. ${ }^{35}$ When laparotomy was performed in suspected ileus, distention of small bowel loops and thickening of the jejunum wall distal to Treitz's ligament with diffuse subserosal bleeding were reported. ${ }^{22}$ Follow-up studies performed on a restricted diet in asymptomatic patients documented resolution of radiologic abnormalities.

\section{OFC in FPIES}

OFCs can be used to establish diagnosis of FPIES or to determine whether FPIES has resolved. According to one conservative approach, follow-up challenges are recommended every 18-24 months in patients without recent reactions.

OFC in FPIES should be performed under physician supervision. ${ }^{1}$ A placement of a secure peripheral venous access before the OFC is recommended for those patients with past severe reactions and is advisable in 


\section{Condition}

Gastrointestinal viral illness or food poisoning

Sepsis

Anaphylaxis

Inborn errors of metabolism

Congenital methemoglobinemia

Cardiovascular or neurologic disorders

Gastroesophageal reflux disease

Intussusception

Hirschprung disease

NEC

Proctocolitis

Food protein-induced enteropathy

Eosinophilic gastroenteropathies
Distinction from FPIES

Fever and sick contacts are typically present, emesis unrelated to ingestion of the same particular food

Antibiotics required for recovery

Symptom onset acute ( $\sim 0.5-1$ hour), IgE-mediated symptoms involving the skin or respiratory system are present, epinephrine helpful

Developmental delay, neurologic manifestations, organomegaly

Cyanosis in an otherwise asymptomatic infant

Acute reaction on reexposure to particular foods missing, gastrointestinal symptoms less prominent

Only upper intestinal symptoms are present

Intermittent, severe, crampy, progressive abdominal pain episodes

The characteristic delay in passage of the first meconium, fever, and abdominal distention

Apnea or respiratory failure, prominent abdominal distention, and tenderness present

Infant is typically well appearing and thriving, exclusively breastfed

Acute reaction on reexposure missing, vomiting less prominent, less severe presentation with no bloody diarrhea, methemoglobinemia, or acidemia

Acute onset (approximately two hours) of gastrointestinal and systemic symptoms is missing, more often positive IgE tests and multiple food triggers

FPIES = food protein-induced enterocolitis syndrome; NEC = necrotizing enterocolitis. Source: Ref. 3. Reprinted with permission from Järvinen and Nowak-Wegrzyn.

infants and older patients with anticipated difficult i.v. access. In the published studies, between $45 \%$ and $95 \%$ of the reactions during the challenge were treated with i.v. fluids and/or steroids. ${ }^{5,31}$ Guidelines for FPIESOFC are presented in Table $4 .{ }^{3,5,36}$ The criteria for OFC positivity have been proposed by Powell ${ }^{18}$ and modified by Sicherer et al..$^{5}$ (Table 4 ).

\section{Management}

Management relies on the food avoidance, prompt treatment of accidental reactions, anticipatory guidance regarding introduction of new foods, and periodic reevaluations for tolerance.

\section{Avoidance}

The principles of avoidance are similar to IgE-mediated food allergy. Extensively hydrolyzed casein formula is recommended for infants that cannot breastfeed, because concomitant CM and soy FPIES occur in up to $40 \%$ of cases. ${ }^{6,9}$ In the majority of infants with CM and/or soy FPIES, symptoms resolve within 3-10 days of starting extensively hydrolyzed casein formula. Rarely, patients need amino acid-based formula or bowel rest and temporary i.v. fluids. ${ }^{9}$ Infants with multiple food FPIES, especially those breastfed are at risk to develop food refusal and may benefit from feeding therapy. 37,38

\section{Treatment of Acute FPIES Reactions}

Rapid i.v. hydration (20-mL/kg normal saline bolus) is the first-line therapy for the severe acute reactions at large or during OFC. I.v. corticosteroids are often used for severe reactions, based on the presumed $\mathrm{T}$ cellmediated intestinal inflammation. Epinephrine should be available for potential severe cardiovascular reactions with hypotension and shock. However, administration of epinephrine does not improve the symptoms of emesis and lethargy, which, however, resolve promptly with vigorous i.v. fluid administration. ${ }^{16}$

A small case series suggested effectiveness of i.v. ondansetron for stopping emesis induced during FPIES OFC. ${ }^{39}$ Five children older than three years with emesis during FPIES OFC were treated with ondansetron, $0.2 \mathrm{mg} / \mathrm{kg}$ per dose together with i.v. physiologic saline bolus. Three of the four children treated with i.v. ondansetron experienced resolution 
Table 4. Oral food challenge for FPIES

Basic requirements

Baseline laboratory tests

Challenge administration

Treatment of the reaction

Postchallenge laboratory tests

Postchallenge observation

Criteria for positive challenge
Physician supervision

Consider securing peripheral intravenous access*

Immediate availability of fluid resuscitation

Peripheral neutrophil count (CBC with differential)

Food amount is calculated as $0.06-0.6 \mathrm{~g}^{* *} / \mathrm{kg}$ body weight in three equal doses, generally not to exceed total 3-g protein or $10 \mathrm{~g}$ of total food (100 mL of liquid)

Food is divided in three equal portions and fed over 30 minutes if foodspecific $\operatorname{IgE}$ is negative

Modification of the challenge and more incremental dosing is used for patients with positive food-specific IgE due to the risk for immediate reactions

Fluid resuscitation: $20-\mathrm{mL} / \mathrm{kg}$ intravenous boluses of normal saline Steroids: methylprednisolone $1-\mathrm{mg} / \mathrm{kg}$ intravenous, $\max 60-80 \mathrm{mg}$ A majority (more than $50 \%$ ) of positive challenges require treatment with intravenous fluids and steroids

The role of intravenous ondansetron $0.2 \mathrm{mg} / \mathrm{kg}$ per dose in the management of acute FPIES reactions is being currently evaluated

Epinephrine and antihistamines do not appear to resolve emesis and lethargy in FPIES; however, vasopressors may be necessary for management of shock

Peripheral neutrophil count (CBC with differential): at six hours if the patient reacted or at discharge if the patients tolerated the challenge

If stool sample available: test for occult blood and stool smear for leukocytes

About six hours after the resolution of symptoms or four hours after feeding in case of no symptoms

Emesis (typically in one to three hours), diarrhea (typically in five to eight hours), fecal leukocytes, fecal eosinophils, and increase in peripheral neutrophil count more than 3500 cells $/ \mathrm{mm}^{3}$ peaking at six hours. The challenge is considered positive when three of five criteria positive, and equivocal when two of five criteria are met. However, in the more recent reports, diarrhea was not observed during the OFC as frequently and the magnitude of neutrophil increase was not as pronounced as reported by Powell. 8,9 Therefore, the diagnostic criteria may need to be modified. The international work group has been formed by the AAAAI and the IAFPE to update the diagnostic guidelines for FPIES. The guidelines are expected to be published in 2015.

FPIES $=$ food protein-induced enterocolitis syndrome; OFC $=$ oral food challenge; IAFPE = International Association for Food Protein Enterocolitis; ${ }^{*}=$ consider securing venous access prior to the challenge in the patients with previous history of severe reactions or those with anticipated difficult access, e.g., infants; ${ }^{* *}=$ lower challenge doses are used for patients with history of severe reactions.

Source: Ref. 56. Reprinted with permission from Nowak-Wegrzyn and Konstantinou.

of emesis and lethargy within 10-15 minutes, whereas one required an additional ondansetron dose. Another child, treated with oral ondansetron, required an additional i.v. ondansetron dose to improve severe abdominal pain. Another small case series in young Italian children reported effectiveness of intramuscular ondansetron for management of acute FPIES in young children during OFC in the physician's office. ${ }^{40}$ Ondansetron is a serotonin 5-hydroxytryptamine receptor antagonist used to treat nausea and vomiting, often after chemotherapy but also in viral gastroenteritis. Ondansetron reduces central and peripheral vagus activity. Ondansetron is generally well tolerated; special caution may be warranted in children with underlying heart disease, due to the potential to prolong QT interval. 


$\begin{array}{ccc}\text { Milk/Soy } & \text { Solid Food } & \text { Milk/Soy and Solid } \\ \text { FPIES } & \text { FPIES } & \text { Food FPIES }\end{array}$

0-12 months

Avoid CM and soy

Exclusive breastfeeding ${ }^{1}$ or extensively hydrolyzed casein

formula $^{2}$ or consider soy OFC in case of milk FPIES

Introduce yellow vegetables

Avoid grains ${ }^{3}$, legumes, poultry

more than 12 months

Avoid trigger foods, OFC with reactive food every 18 months

Exclusive breastfeeding ${ }^{1}$ or extensively hydrolyzed casein

formula $^{2}$ or consider soy OFC in case of milk FPIES

Consider OFC with milk or soy if not tried

Consider OFC with grains, legumes, poultry if not tried

$\begin{array}{ccc}X & & \\ X & & X \\ X & X & X \\ & X^{4} & X^{4} \\ X & X & X \\ X & & X \\ X & X & X \\ & & X^{4}\end{array}$

No controlled trials have been performed to determine optimal timing of introduction in infants and toddlers with FPIES.

FPIES $=$ food protein-induced enterocolitis syndrome; OFC $=$ oral food challenge; $C M=$ cow's milk.

${ }^{1}$ No maternal elimination diet recommended unless reactions to food through breast milk.

${ }^{2}$ If not tolerated, an amino acid based formula should be initiated.

${ }^{3}$ Including oat, rice, wheat, barley, or rye.

${ }^{4}$ Oral food challenges may be necessary to introduce new solid foods to children with multiple food FPIES.

Source: Ref. 3. Reprinted with permission from Järvinen and Nowak-Wegrzyn.

Emergency treatment plans outlining clinical features and management of acute reactions should be provided to patients with FPIES (a template can be accessed on the International Association for Food Protein Enterocolitis website, http://iaffpe.org/docs/ Emergency_Plan.pdf). Mild reactions may be managed with careful oral rehydration at home. Patients with more severe reactions require resuscitation in the emergency department or inpatient unit.

\section{Introduction of New Foods}

The empiric guidelines for food introduction are presented in Table 5 (see also Fig. 1).

\section{Periodic Reevaluations to Assess for Resolution of FPIES}

Foods that have caused FPIES reactions in the past should generally be reintroduced under physician supervision during a formal OFC.

The timing of OFCs to determine resolution has not been systematically investigated. In the United States experience, a diagnostic OFC is usually attempted within 12-18 months after the most recent reaction. ${ }^{3,32}$ However, a prospective study from Korea suggested that earlier rechallenging might be considered. ${ }^{10}$ In that study, among 23 infants with CM or soy FPIES (diagnosed at a median age 36 days, range 13-58 days) followed until two years of age, tolerance rates to CM and soy were $27 \%$ and $75 \%$ at six months, $42 \%$ and $91 \%$ and eight months, and $64 \%$ and $92 \%$ at 10 months, respectively. CM FPIES resolved in all children by age two years; soy FPIES resolved by age 14 months. In a prospective cohort study from Israel, all children were diagnosed with CM FPIES by age six months, and $50 \%$ of them resolved CM FPIES within first year of life, $89 \%$ by age two years, and $90 \%$ by age three years. ${ }^{8}$ In contrast, retrospective studies from the United States report lower rates of resolution of FPIES to CM or soy, $35 \%$ by age two years, $70 \%$ by age three years, and $85 \%$ by age five years. ${ }^{6,9}$ These differences may reflect various study designs and/or selection bias toward more severe and persistent phenotype among children evaluated at the referral allergy centers compared with those identified from general population. Current data support performing OFCs to CM after 12 months of age, whereas soy challenges may be considered after six months of age. ${ }^{9,10,41}$

There are no data on resolution of FPIES to seafood in older children and adults. Periodic reevaluations should be considered in these patients

\section{IgE Testing in FPIES}

FPIES is classified as a non-IgE-mediated disorder, because in the majority of the patients, systemic IgE antibodies specific for the FPIES food are undetectable. ${ }^{1,19,42,43}$ Studies report that $4-25 \%$ of children diagnosed with FPIES initially have or develop foodspecific IgE.6,8,9 Children with CM FPIES who develop systemic CM-specific IgE appear to have delayed resolution of FPIES. ${ }^{5,9,32}$ Most of the children with food- 


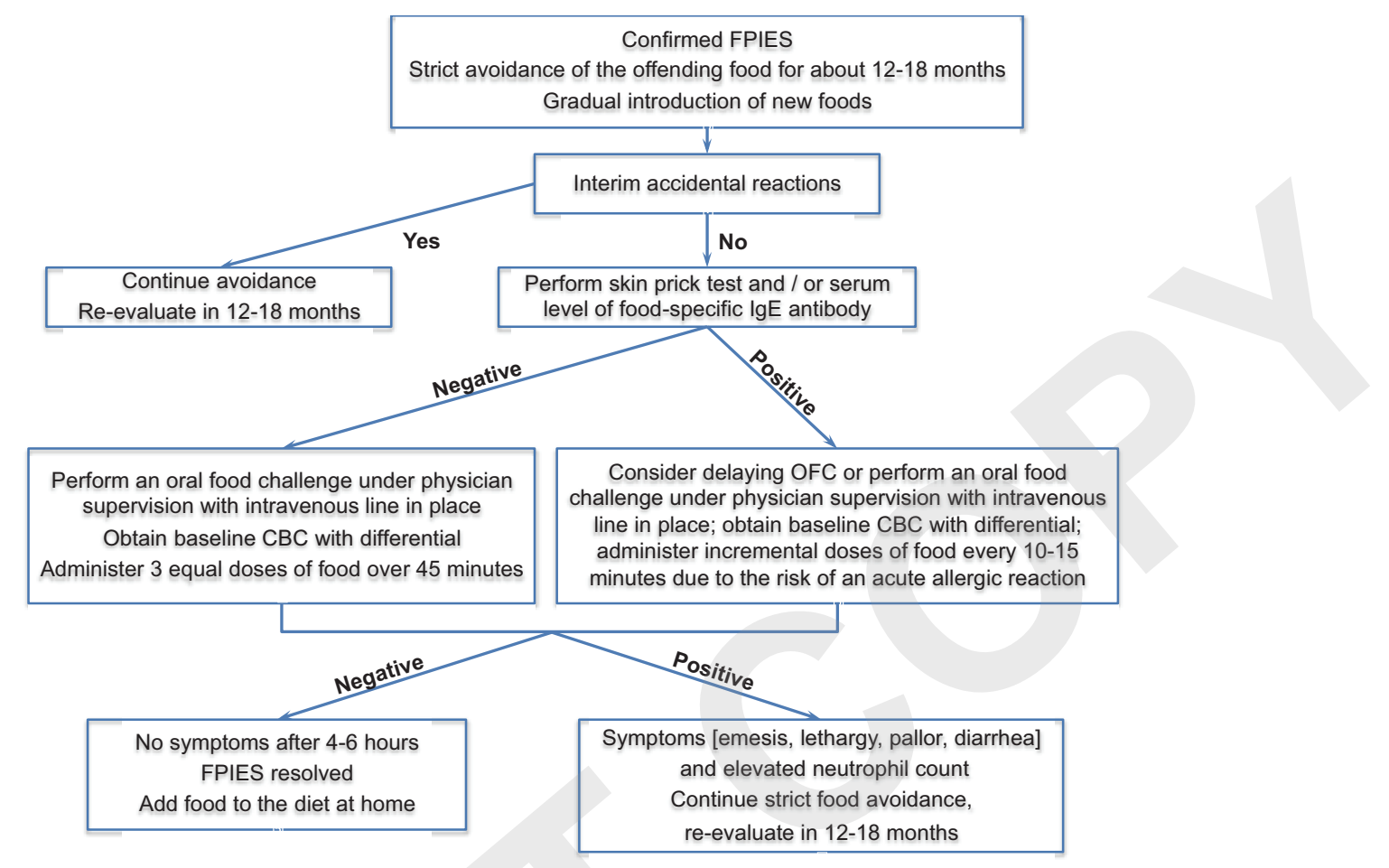

Figure 1. Empiric management of FPIES. Source: Ref. 56. Reprinted with permission from Nowak-Wegrzyn and Konstantinou.

specific IgE antibodies retain the FPIES phenotype. However, a subset may change to immediate IgE-mediated food allergy. In one study, $35 \%$ of the children with CM-induced FPIES who developed CM-specific IgE antibodies experienced immediate allergic manifestations of CM allergy. ${ }^{9}$ Although this observation needs to be validated in prospective studies, we recommend allergy evaluations for food specific IgE before performing an OFC to the FPIES food and, if positive, to modify the challenge procedure to administer incrementally increasing doses of the food, as per the standard for challenges for IgE-mediated food allergy. ${ }^{1,44}$ The food APT is not routinely recommended for follow-up evaluation in FPIES. ${ }^{6,33,34}$

\section{Natural History}

In general, FPIES is a self-limiting condition that resolves with age and has no long-lasting sequelae. ${ }^{2}$ The data on FPIES resolution vary widely, depending on the food and the population studied. ${ }^{45}$ In the Israeli population-based cohort, $90 \%$ of CM FPIES resolved by age three years. ${ }^{8}$ In a small prospective study from Korea, among 23 infants with CM or soy FPIES, CM FPIES resolved in all children by age two years; soy FPIES resolved by age 14 months. ${ }^{10}$ In a retrospective United States study, overall significantly lower rates of resolution of FPIES were found, 35\% by age two years, $70 \%$ by age three years, and $85 \%$ by age five years. ${ }^{6}$ In a mixed-design United States study, overall median age at resolution of CM FPIES was 13 years, whereas the median age for patients with undetectable CM- $\operatorname{IgE}$ was five years. ${ }^{9}$ These differences may reflect differences in study designs and/or selection bias toward more severe and persistent phenotype among children evaluated at the referral allergy centers compared with those identified from general population. The age of resolution of solid FPIES is older, approximately $50 \%$ of children outgrow rice or oat FPIES by age four to five years. ${ }^{6,9,45}$ There are no data on resolution of FPIES to seafood in older children and adults.

FPIES rarely develops to foods upon initial feeding beyond one year of age, although onset of FPIES to fish and shellfish has been reported in older children and adults. For example, wheat allergy has not been reported in infants with oat- or rice-induced FPIES, but introduction of wheat was significantly delayed, presumably avoiding the "window of physiologic susceptibility" for FPIES development. ${ }^{2,5}$ Patients presenting initially or developing food-specific IgE antibodies after the diagnosis of FPIES appear to have a more protracted course. ${ }^{5,13}$ It is prudent to include prick skin testing and/or measurement of serum food-specific IgE level in the initial as well as follow-up evaluations, to identify patients at risk for persistent FPIES.

\section{Pathophysiology of FPIES}

The mechanisms underlying FPIES remain poorly characterized and are summarized in Box 1. 2,39,46 


\section{Box 1. Pathophysiology of FPIES}

There is evidence of $\mathrm{T}$ cell proliferation upon stimulation with food antigens; however, the stimulation index is not consistently different from control, nonallergic subjects.

$\mathrm{T}$ cell activation by food allergens may mediate local intestinal inflammation through release of proinflammatory cytokines, e.g., TNF- $\alpha$ and IFN- $\gamma$, causing increased intestinal permeability and fluid shift. ${ }^{2}$

Local inflammation may be mediated by activated peripheral mononuclear cells, increased TNF- $\alpha$, and decreased expression of TGF- $\beta$ receptors in the intestinal mucosa. ${ }^{46}$

Leukocytosis and thrombocytosis are frequently observed in FPIES reactions and are thought to reflect an inflammatory response.

Humoral responses are poorly characterized in FPIES; IgE, IgA, and IgG4 antibody responses to casein are generally suppressed.

A recent case series of children with FPIES successfully treated with intravenous ondansetron during the supervised oral food challenge raised questions about the role of serotonin signaling in FPIES. ${ }^{39}$

The effectiveness of ondansetron (serotonin $5-\mathrm{HT}_{3}$ receptor antagonist that reduces peripheral and central activity of the vagus nerve) suggests the potential role of a neuroendocrinologic pathway in FPIES reactions.

\section{Box 2. Biopsy findings in FPIAP}

Prominent eosinophilic infiltrates in the rectal mucosa.

The number of eosinophils varies from 6 to more than 20 per $40 \times \mathrm{hpf}$.

Eosinophils are frequently degranulated and localized next to the lymphoid nodules. ${ }^{48,52,55}$

There is no correlation between the degree of peripheral blood eosinophilia and the tissue eosinophilic infiltrate within the rectosigmoid.

Eosinophil mediators induce mast cell degranulation, dysfunction of vagal muscarinic M2 receptors, smooth muscle constriction, and stimulation of chloride secretion from colonic epithelium.

Degranulation of the eosinophils near nerves may contribute to gastric dysmotility. Experimental eosinophil accumulation in the gastrointestinal tract is associated with the development of weight loss. ${ }^{48}$

\section{FPIAP}

\section{Introduction}

FPIAP is a benign transient condition, which typically starts in the first few months of life with bloodstreaked stools in well-appearing infants; it is considered a one of the major causes of colitis under age one year (Table 5). ${ }^{1,47,48}$ Food protein-induced proctocolitis was originally described by Lake et al. in 1982 in six exclusively breastfed infants with rectal bleeding that appeared during the first month of life. ${ }^{49}$

\section{Offending Foods}

Approximately $60 \%$ of cases occur in breastfed infants, where the immune response results from maternal ingestion of the food allergen, usually $\mathrm{CM}$, which is passed in immunologically recognizable form into the breast CM. In formula-fed infants, the reaction is associated with CM or, less commonly, soy. ${ }^{49,50}$ The disorder has rarely been described in infants fed hypoallergenic, extensively hydrolyzed formulas $(\sim 4 \%-10 \%)$.

\section{Epidemiology}

In contrast to other forms of gastrointestinal food hypersensitivity, FPIAP is common in breastfed infants, accounting as many as $60 \%$ of cases in published reports. ${ }^{51}$ Anecdotally, FPIAP is common in countries with a lower prevalence of food allergy such as Greece and Brazil. The exact prevalence of FPIAP is unknown; the estimated prevalence ranges from $18 \%$ to $64 \%$ of the infants with rectal bleeding. ${ }^{50,52}$ Eczema is present in approximately $22 \%$ of the breastfed infants. Positive family history of atopy is present in up to $25 \%$ of infants with FPIAP.

\section{Clinical Features}

FPIAP in formula-fed infants is typically caused by $\mathrm{CM}$ and soy proteins; FPIAP in breastfed infants is usually caused by CM, soy, egg, and corn proteins. Infants usually present in the first six months of life, usually at one to four weeks of age with intermittent blood-streaked normal to moderately loose stools (Table 1). Breastfed infants are often older at the time of initial presentation and have less severe histologic findings. ${ }^{49,51,52}$ The bleeding is often attributed to perirectal fissures. However, bleeding associated with fissures tends to present with streaks of blood on hard, formed stool, whereas FPIAP presents with blood mixed in frothy, mucousy stool. Rarely, colic or increased frequency of bowel movements may be reported, but failure to thrive is absent. Children with 
FPIAP may develop mild anemia or hypoalbuminemia. Some have peripheral blood eosinophilia, elevated serum IgE antibody levels, and a positive family history of atopy. The onset may be acute (less than 12 hours after the first feeding of the offending food), but usually it is insidious, with a prolonged latent interval between the introduction of the food protein and the appearance of symptoms. The infants typically appear well. However, increased gas (up to $30 \%$ of patients), intermittent emesis (up to 27\%), pain on defecation $(22 \%)$, or abdominal pain (up to $20 \%$ ) may be present. No anatomic abnormalities are found, and stool cultures are negative for pathogens. Smears of the fecal mucus usually reveal increased polymorphonuclear neutrophils.

\section{FPIAP in Breastfed Infants}

Breastfed infants react to the food proteins consumed by the mother. Elimination of offending food from the mother's diet usually results in gradual resolution of symptoms in the infants and permits the continuation of breastfeeding. ${ }^{51}$ Rarely, a casein hydrolysate formula, or an amino acid-based formula, may be necessary for resolution of bleeding, typically within $48-72$ hours.

Breastfed infants occasionally continue to have bleeding despite maternal avoidance of food(s). Six of the 21 of these infants developed iron deficiency anemia despite iron supplementation, but they gained weight and had normal development; they tolerated a regular diet by the first birthday. ${ }^{51}$ The persistence of rectal bleeding despite maternal dietary restrictions may be explained by inability to remove all sources of allergen from the diet or by an allergen that has not been identified. Alternatively, the baby might react to the human breast protein.

\section{Diagnosis}

Diagnosis relies on history of rectal bleeding, exclusion of infections and other causes of rectal bleeding, and response to an elimination diet, which typically leads to a clinical resolution of gross bleeding within 72-96 hours. ${ }^{51}$ Occult blood may persist for longer. Tests for IgE-mediated food hypersensitivity are negative or inconsistent and usually not useful for the diagnosis of FPIAP, unless the condition is associated with atopic features, such as atopic dermatitis. Exclusion of causes of rectal bleeding, such as infection, necrotizing enterocolitis, intussusception, or anal fissure, is important (Table 6).

\section{Management}

Treatment relies on dietary restriction. In the breastfed infants, Lake proposed discontinuation of breast milk and feeding with a casein hydrolysate formula
Table 6. Differential diagnosis of rectal bleeding in infancy

\begin{tabular}{ll}
\hline Severe & Necrotizing Enterocolitis \\
& Sepsis \\
& Hirschprung's disease \\
& Intussusception \\
& Volvulus \\
& FPIES \\
Mild/moderate & Anal fissure \\
& Perianal dermatitis/excoriations \\
& Gastrointestinal infection (Salmonella, \\
& Shigella, Campylobacter, Yersinia sp, \\
& parasites) \\
& Coagulation disorders \\
& Vitamin K deficiency \\
& FPIAP
\end{tabular}

FPIES = food protein-induced enterocolitis syndrome; FPIAP $=$ food protein-induced allergic proctocolitis.

until resolution of bleeding, usually within 72 hours. ${ }^{49}$ Soy formula may cause bleeding in a large subset of infants reacting to CM, because up to $40 \%$ of infants react to both foods. ${ }^{17}$ Most infants respond well to casein hydrolysate, and only a few require amino acidbased formulas. Breastfeeding mothers must strictly avoid the offending food protein in their diet. Rechallenge within the first six months usually induces recurrence of bleeding within 72 hours. In contrast to FPIES, no peripheral blood leukocytosis is seen after the challenge. ${ }^{6,14}$ With negative skin-prick tests and serum food-specific IgE antibody levels, food introduction typically takes place at home, with gradual increase from $1 \mathrm{oz} /$ day to full feedings over two weeks. ${ }^{24}$

\section{Natural history}

Infants with proctocolitis become tolerant to the offending food by one to three years of age and the majority achieves clinical tolerance by one year. Up to $20 \%$ of breastfed infants have spontaneous resolution of bleeding without changes in the maternal diet. ${ }^{53}$ The long-term prognosis is excellent, there are no reports of the inflammatory bowel disease in infants with FPIAP followed for more than 10 years. ${ }^{51,54}$

\section{Pathophysiology}

FPIAP predominantly affects the rectosigmoid. Endoscopy reveals focal erythema with lymphoid nodular hyperplasia. Biopsy findings are summarized in Box 2. ${ }^{48,52,55}$

\section{SUMMARY}

FPIES and FPIAP are common childhood conditions with favorable prognosis; majority of cases resolve in 
the first few years of life. Diagnosis is hampered by the lack of noninvasive confirmatory tests and tests that identify the offending food proteins. Management relies on the avoidance of the offending food and periodic reintroductions.

\section{REFERENCES}

1. Boyce JA, Assa'ad A, Burks AW, et al. Guidelines for the diagnosis and management of food allergy in the United States: summary of the NIAID-Sponsored Expert Panel Report. J Allergy Clin Immunol 126:1105-1118, 2010.

2. Caubet JC, and Nowak-Węgrzyn A. Current understanding of the immune mechanisms of food protein-induced enterocolitis syndrome. Expert Rev Clin Immunol 7:317-327, 2011.

3. Järvinen KM, and Nowak-Wẹgrzyn A. Food protein-induced enterocolitis syndrome (FPIES): current management strategies. J Allergy Clin Immunol Pract 1:317-322, 2013.

4. Feuille E, and Nowak-Węgrzyn A. Definition, etiology, and diagnosis of food protein-induced enterocolitis syndrome. Opin Allergy Clin Immunol 14:222-228, 2014.

5. Sicherer SH, Eigenmann PA, and Sampson HA. Clinical features of food protein-induced enterocolitis syndrome. J Pediatr 133:214-219, 1998.

6. Ruffner MA, Ruymann K, Barni S, et al. Food protein-induced enterocolitis syndrome: insights from review of a large referral population. J Allergy Clin Immunol Pract 1:343-349, 2013.

7. Mehr S, Kakakios A, Frith K, and Kemp AS. Food proteininduced enterocolitis syndrome: 16-year experience. Pediatrics 123:e459-e464, 2009.

8. Katz Y, Goldberg MR, Rajuan N, et al. The prevalence and natural course of food protein-induced enterocolitis syndrome to CM: a large-scale, prospective population-based study. J Allergy Clin Immunol 127:647-653.e1-3, 2011.

9. Caubet JC, Ford LS, Sickles L, et al. Clinical features and resolution of food protein-induced enterocolitis syndrome: 10-year experience. J Allergy Clin Immunol 134:382-389, 2014.

10. Hwang JB, Sohn SM, and Kim AS. Prospective follow-up oral food challenge in food protein-induced enterocolitis syndrome. Arch Dis Child 94:425-428, 2009.

11. Hwang JB, Lee SH, Kang YN, et al. Indexes of suspicion of typical cow's milk protein-induced enterocolitis. J Korean Med Sci 22:993-997, 2007.

12. Monti G, Castagno E, Liguori SA, et al. Food protein-induced enterocolitis syndrome by cow's milk proteins passed through breast milk. J Allergy Clin Immunol 127:679-80, 2011.

13. Tan J, Campbell D, and Mehr S. Food protein-induced enterocolitis syndrome in an exclusively breast-fed infant-an uncommon entity. J Allergy Clin Immunol 129:873, author reply 873874, 2012.

14. Nomura I, Morita H, Hosokawa S, et al. Four distinct subtypes of non-IgE-mediated gastrointestinal food allergies in neonates and infants, distinguished by their initial symptoms. J Allergy Clin Immunol 127:685-688.e1-8, 2011.

15. Nomura I, Morita H, Ohya Y, et al. Non-IgE-mediated gastrointestinal food allergies: distinct differences in clinical phenotype between Western countries and Japan. Curr Allergy Asthma Rep 12:297-303, 2012.

16. Fernandes BN, Boyle RJ, Gore C, et al. Food protein-induced enterocolitis syndrome can occur in adults. J Allergy Clin Immunol 130:1199-1200, 2012.

17. Gryboski JD. Gastrointestinal milk allergy in infants. Pediatrics 40:354-362, 1967.

18. Powell GK. Milk- and soy-induced enterocolitis of infancy. Clinical features and standardization of challenge. J Pediatr 93:553-560, 1978.
19. Nowak-Wegrzyn A, Sampson HA, Wood RA, and Sicherer SH. Food protein-induced enterocolitis syndrome caused by solid food proteins. Pediatrics 111:829-835, 2003.

20. Murray KF, and Christie DL. Dietary protein intolerance in infants with transient methemoglobinemia and diarrhea. J Pediatr 122:90-92, 1993.

21. Coates RW, Weaver KR, Lloyd R, et al. Food protein-induced enterocolitis syndrome as a cause for infant hypotension. West J Emerg Med 12:512-514, 2011.

22. Jayasooriya S, Fox AT, and Murch SH. Do not laparotomize food-protein-induced enterocolitis syndrome. Pediatr Emerg Care 23:173-175, 2007.

23. Borchers SD, Li BU, Friedman RA, and McClung HJ. Riceinduced anaphylactoid reaction. J Pediatr Gastroenterol Nutr 15:321-324, 1992.

24. Cavataio F, Carroccio A, Montalto G, and Iacono G. Isolated rice intolerance: clinical and immunologic characteristics in four infants. J Pediatr 128:558-560, 1996.

25. Vandenplas Y, Edelman R, and Sacré L. Chicken-induced anaphylactoid reaction and colitis. J Pediatr Gastroenterol Nutr 19:240-241, 1994.

26. Levy Y, and Danon YL. Food protein-induced enterocolitis syndrome-not only due to cow's milk and soy. Pediatr Allergy Immunol 14:325-329, 2003.

27. Zapatero Remon L, Alonso Lebrero E, Martin Fernandez E, and Martinez Molero MI. Food-protein-induced enterocolitis syndrome caused by fish. Allergol Immunopathol (Madr) 33:312316, 2005.

28. Hwang JB, Kang KJ, Kang YN, and Kim AS. Probiotic gastrointestinal allergic reaction caused by Saccharomyces boulardii. Ann Allergy Asthma Immunol 103:87-88, 2009.

29. Hsu P, and Mehr S. Egg: a frequent trigger of food proteininduced enterocolitis syndrome. J Allergy Clin Immunol 131: 241-242, 2013.

30. Arik Yilmaz E, Cavkaytar O, Uysal Soyer O, and Sackesen C. Egg yolk: an unusual trigger of food protein-induced enterocolitis syndrome. Pediatr Allergy Immunol 25:296-297, 2014.

31. Sopo SM, Giorgio V, Dello Iacono I, et al. A multicentre retrospective study of 66 Italian children with food protein-induced enterocolitis syndrome: different management for different phenotypes. Clin Exp Allergy 42:1257-1265, 2012.

32. Sicherer SH. Food protein-induced enterocolitis syndrome: case presentations and management lessons. J Allergy Clin Immunol 115:149-156, 2005.

33. Fogg MI, Brown-Whitehorn TA, Pawlowski NA, and Spergel JM. Atopy patch test for the diagnosis of food protein-induced enterocolitis syndrome. Pediatr Allergy Immunol 17:351-355, 2006.

34. Järvinen KM, Caubet JC, Sickles L, et al. Poor utility of atopy patch test in predicting tolerance development in food proteininduced enterocolitis syndrome. Ann Allergy Asthma Immunol 109:221-222, 2012.

35. Richards DG, Somers S, Issenman RM, and Stevenson GW. Cow's milk protein/soy protein allergy: gastrointestinal imaging. Radiology 167:721-723, 1988.

36. Nowak-Wegrzyn A, Assa'ad AH, Bahna SL, et al. Adverse Reactions to Food Committee of American Academy of Allergy, Asthma \& Immunology. Work Group report: oral food challenge testing. J Allergy Clin Immunol 123:S365-S383, 2009.

37. Groetch M, and Nowak-Wegrzyn A. Practical approach to nutrition and dietary intervention in pediatric food allergy. Pediatr Allergy Immunol 24:212-221, 2013.

38. Groetch M, Henry M, Feuling MB, and Kim J. Guidance for the nutrition management of gastrointestinal allergy in pediatrics. J Allergy Clin Immunol Pract 1:323-331, 2013. 
39. Holbrook T, Keet CA, Frischmeyer-Guerrerio PA, and Wood RA. Use of ondansetron for food protein-induced enterocolitis syndrome. J Allergy Clin Immunol 132:1219-1220, 2013.

40. Sopo SM BA, Greco M, and Monaco S. Ondansetron for food protein-induced enterocolitis syndrome. Arch Allergy Immunol 164:137-139, 2014.

41. Sopo SM, Iacono ID, Greco M, and Monti G. Clinical management of food protein-induced enterocolitis syndrome. Opin Allergy Clin Immunol 14:240-245, 2014.

42. Sampson HA, and Anderson JA. Summary and recommendations: classification of gastrointestinal manifestations due to immunologic reactions to foods in infants and young children. J Pediatr Gastroenterol Nutr 30(Suppl.):S87-S94, 2000.

43. Sicherer SH, Burks AW, and Sampson HA. Clinical features of acute allergic reactions to peanut and tree nuts in children. Pediatrics 102:e6, 1998.

44. Järvinen KM, and Sicherer SH. Diagnostic oral food challenges: procedures and biomarkers. J Immunol Methods 383:30-38, 2012.

45. Katz Y, and Goldberg MR. Natural history of food proteininduced enterocolitis syndrome. Opin Allergy Clin Immunol 14:229-239, 2014.

46. Chung HL, Hwang JB, Park JJ, and Kim SG. Expression of transforming growth factor $\beta 1$, transforming growth factor type I and II receptors, and TNF- $\alpha$ in the mucosa of the small intestine in infants with food protein-induced enterocolitis syndrome. J Allergy Clin Immunol 109:150-154, 2002.

47. Jenkins HR, Pincott JR, Soothill JF, et al. Food allergy: the major cause of infantile colitis. Arch Dis Child 59:326-329, 1984.
48. Goldman H, and Proujansky R. Allergic proctitis and gastroenteritis in children. Clinical and mucosal biopsy features in 53 cases. Am J Surg Pathol 10:75-86, 1986.

49. Lake AM, Whitington PF, and Hamilton SR. Dietary proteininduced colitis in breast-fed infants. J Pediatr 101:906-910, 1982.

50. Arvola T, Ruuska T, Keränen J, et al. Rectal bleeding in infancy: clinical, allergological, and microbiological examination. Pediatrics 117:e760-e768, 2006.

51. Lake AM. Food-induced eosinophilic proctocolitis. J Pediatr Gastroenterol Nutr 30(Suppl.):S58-S60, 2000.

52. Xanthakos SA, Schwimmer JB, Melin-Aldana H, et al. Prevalence and outcome of allergic colitis in healthy infants with rectal bleeding: a prospective cohort study. J Pediatr Gastroenterol Nutr 41:16-22, 2005.

53. Maloney J, and Nowak-Wẹgrzyn A. Educational clinical case series for pediatric allergy and immunology: allergic proctocolitis, food protein-induced enterocolitis syndrome and allergic eosinophilic gastroenteritis with protein-losing gastroenteropathy as manifestations of non-IgE-mediated cow's milk allergy. Pediatr Allergy Immunol 18:360-367, 2007.

54. Hill DJ, Ford RP, Shelton MJ, and Hosking CS. A study of 100 infants and young children with cow's milk allergy. Clin Rev Allergy 2:125-142, 1984.

55. Machida HM, Catto Smith AG, Gall DG, et al. Allergic colitis in infancy: clinical and pathologic aspects. J Pediatr Gastroenterol Nutr 19:22-26, 1994.

56. Nowak-Wegrzyn and Konstantinou G. Non-IgE-mediated food allergy: FPIES. Curr Pediatr Rep 2:135-143, 2014. 